\title{
Glyphidocythere, a new deep marine, paradoxostomatid (Ostracoda) from the Quaternary and Recent of the Indo-Pacific
}

\author{
M.A. AYRESS \\ Department of Geology \\ Australian National University \\ PO Box 4 , \\ Canberra, ACT2601 \\ Australia
}

\author{
T. CORRÈGE \\ Department of Geology \\ Australian National University \\ POB Box 4, \\ Canberra, ACT2601 \\ Australia
}

\author{
R. C. WHATLEY \\ Institute of Earth Studies \\ University College of Wales \\ Aberystwyth \\ Dyfed, SY23 3DB \\ U.K.
}

\begin{abstract}
Chapman's (1910) Pseudocythere funafutiensis from 1924m off Funafuti, western Pacific is redescribed and illustrated together with additional Pleistocene and Recent material from the Coral and Tasman seas. A new paradoxostomatid genus, Glyphidocythere, is described to accommodate it and two other species yet to be formally described from the Banda Sea, eastern Indonesia. The genus is apparently restricted to the marine slope environment of low (less than $20^{\circ}$ ) southern latitudes. In the Coral and Tasman seas $G$. funafutiensis occurs within a narrow bathyal depth range (955m to $1754 \mathrm{~m}$ ) coincident with the Antarctic Intermediate Water. J. Micropalaeontol., 12 (1): 77-79, August 1993.
\end{abstract}

\section{INTRODUCTION}

This paper formally describes a new ostracod genus Glyphidocythere based on disarticulated valves from the Quaternary and Recent of the western Pacific Ocean and the Recent of the Banda Sea, Indonesia.

Chapman (1910) first recorded the new genus from Recent foraminifera ooze off western Funafuti at a depth of 1924m, but assigned his material to a new species of Pseudocythere: $P$. funafutiensis. The total number of specimens that Chapman collected is unknown, and few details regarding their depository were reported. Chapman did indicate, however, that the types were deposited at the British Museum of Natural History but he did not assign catalogue numbers to his material and apparently none were formally recorded at the museum. After a search through the collections at the museum (by M. Ayress) Chapman's (1910) type material from Funafuti was located and only one specimen, the holotype, of $P$. funafutiensis was present. The specimen has been examined for this study and although badly damaged is illustrated here. The species is more fully described below and shown to belong to a new genus (also described below) of the Paradoxostomatidae.

All of our material from the Coral Sea (Late Pleistocene and Recent) and the Tasman Sea (Early Pleistocene) is included within G. funafutiensis (Chapman), here designated the type species of Glyphidocythere gen. nov. Meyboom (lit.comm. 1991) has also shown us modern material from the Banda Sea, Indonesia which includes G. funafutiensis, and also two additional, as yet undescribed species of this genus.

\section{MATERIAL}

All records of $G$. funafutiensis and locality details are shown in Table 1.

Chapman's holotype is deposited and curated in the British Museum of Natural History No. 1911.11.7.50. Other material illustrated here is deposited at the National Museum of Victoria to which the catalogue numbers with prefix NMVP apply.

\section{SYSTEMATIC DESCRIPTIONS}

The following abbreviations are used:

$\mathrm{A}=$ Adult, $\mathrm{LV}=$ left valve, $\mathrm{RV}=$ right valve.

Superfamily Cytheracea Baird, 1850

Family Paradoxostomatidae Brady \& Norman,. 1889

Genus Glyphidocythere gen. nov.

Type species: Pseudocythere funafutiensis Chapman, 1910 here designated.

Derivation of name: Greek, Glyphidos = knife, referring to the knife-like appearance of the species in this genus.

Diagnosis: A large, extremely thin-shelled, paradoxostomatid genus with an acuminate anterior margin and a caudal process at or above mid-height. Carapace compressed with maximum inflation above mid-height. Dorsal margin straight to gently convex with a narrow low flange; ventral margin weakly biconvex. Inner lamella very wide with undulating inner margin medianly and a small vestibulum anteriorly; posteroventral vestibulum very narrow. Hinge lophodont with small anti-slip tooth in RV.

Remarks: The acuminate anterior, undulating inner margin and four adductor muscle scars serve to distinguish this genus from superficially similar bythocytherid genera such 
as Pseudocythere, Jonesia and Baltraella.

Its four adductor muscle scars arranged in an oblique, closely spaced pattern, and the compressed thin shelled carapace are typical features of the Paradoxostomatidae. Within that family Glyphidocythere is most similar to Paradoxostoma and Machaerina. Those genera, particularly the former, display considerable variation in outline and some species are close in this respect to Glyphidocythere. Paradoxostoma from the Red Sea for example (illustrated by Bonaduce et al., 1980, Pls 10, 12 \& 13) has a wide range of lateral outline, of which $P$. subtile Bonatuce et al. is most similar to G. funafutiensis. P. lizardensis Behrens, 1991, from the Great Barrier Reef, is also very similar in outline. However, Glyphidocythere differs from both Paradoxostoma asnd Machaerina, mainly in its undulating inner margin, its dorsal flange and in its very narrow postero-ventral vestibulum. Also the maximum inflation is often below midheight in Paradoxostoma not at or above mid-height as it is in Glyphidocythere. Paradoxostoma usually ranges in length between $0.50 \mathrm{~mm}$ to $0.70 \mathrm{~mm}$ with some species rarely $0.85 \mathrm{~mm}$ (Van Morkhoven, 1963). Glyphidocythere is always longer than $0.75 \mathrm{~mm}$, with some specimens reaching a length of $1 \mathrm{~mm}$. Only in Machaerina is this large size attained.

Glyphocythere shares with some species of Pseudocythere, Paracytherois and Paradoxostoma similar longitudinal striations on the external valve surface. This feature is not of taxonomic importance at the generic level, and, while its function is uncertain, it clearly has been developed convergently.

Glyphidocythere funafutiensis (Chapman, 1910)

(Pl. 1, figs 1-9, pl.2, figs 1-6, Fig. 1.)

1910 Pseudocythere funafutiensis Chapman p.438, pl.57, fig.28. Material and dimensions: 29 adult valves

\begin{tabular}{|c|c|c|}
\hline Off Funafuti(Chapman, 1910) & Length (mm) & Height (mm) \\
\hline ARV Holotype BMNH 1911.11.7.50 & 0.99 & 0.28 \\
\hline \multicolumn{3}{|l|}{ Tasman Sea } \\
\hline ALV NMVP 197929 & 0.84 & 0.25 \\
\hline ALV NMVP 197930 & 0.96 & 0.28 \\
\hline \multicolumn{3}{|l|}{ Coral Sea } \\
\hline ALV NMVP 197931 & broken & 0.24 \\
\hline ARV NMVP 197932 & 0.80 & 0.22 \\
\hline ALV NMVP 197933 & 0.79 & 0.22 \\
\hline
\end{tabular}

Emended diagnosis: A species of Glyphidocythere with an acuminate anterior margin, a dorsal caudal process and subparallel dorsal and ventral margins through median third of length. Dorsal margin with narrow rimmed flange. Lateral surface covered with fine longitudinal striations.

Description: Large, elongate and thin-shelled. Anterior margin acuminate with convex apex just above mid-height.

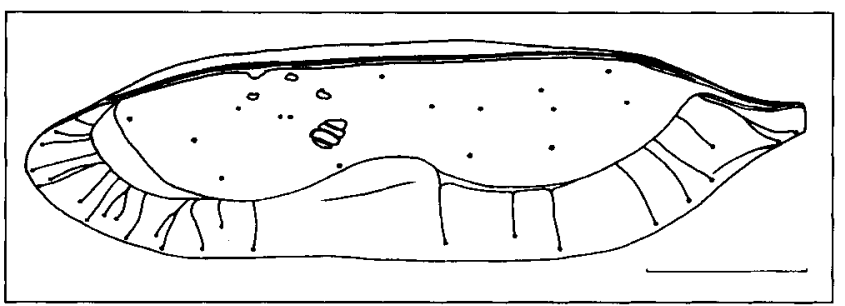

Fig. 1 Adult right valve of Glyphidocythere funafutiensis (Chapman, 1910) (NMVP 197930) seen in transmitted light. Length of scale bar $-0.2 \mathrm{~mm}$.

Posterior margin with well-developed caudal process dorsally. Dorsal margin straight medianly and bears narrow flange-like rim; anterior and posterior slopes slightly concave. Ventral margin gently biconvex with narrow rim medianly. Carapace compressed; maximum inflation at dorsal third of height. Lateral surface covered with fine sinuous longitudinal striations. Normal pore canals sparse and simple. Inner lamella broad with undulating inner margin. Small vestibulum anteriorly and a very narrow vestibulum postero-ventrally. Inner margin rimmed at caudal process. Radial pore canals long and slightly curved, some branching; about 13 anteriorly, 6 posteriorly. Hinge lophodont; in RV: narrow median groove, anti slip tooth at anterior quarter of valve length; in LV, median bar slightly lobate at posterior end, and narrow terminal sockets accommodate edges of RV at each end. Adductor muscle scars consist of an ovate aggregate of four elongate scars in an oblique row: the dorsal most scar sub-triangular, the median two sub-rectangular, the posterior most scar subovate. Dorsal edge of scar aggregate raised in a boss-like protrusion. Sexual dimorphism not apparent.

Remarks: The inner lamella of this species is extremely thin and usually broken in fossil material. G. funafutiensis differs from two other, as yet undescribed, species from the Banda Sea in its larger size, its more acuminate anterior, its almost parallel dorsal and ventral margins, its well developed caudal process, its surface striations and its less undulating inner margin.

Distribution: Recent off west coast of Funafuti, water depth 1924m (Chapman, 1910); Late Pleistocene to Recent of Coral Sea, water depths between 955m and 1754m; Early Pleistocene of Tasman Sea, present day water depth 1533m; Recent of Banda Sea, eastern Indonesia, water depths between $618 \mathrm{~m}$ and $627 \mathrm{~m}$.

\section{DISCUSSION}

Table 1 lists the known records of Glyphidocythere. The genus appears to enjoy a restricted geographical and bathymetric distribution: west of Funafuti, Coral Sea, northern Tasman Sea and eastern Banda Sea, at water depths greater than $500 \mathrm{~m}$ and less than $2000 \mathrm{~m}$. Other genera which occupy

\section{Explanation of Plate 1}

All figures Glyphidocythere funafutiensis (Chapman). All dimensions are given as length $\mathrm{x}$ height in $\mathrm{mm}$.

Figs 1-2 Holotype ARV, $0.99 \times 0.28$, 1924m off Funafuti, BM(NH) 1911.11.7.50: Fig.1, ext. lat.; Fig.2, detail of median surface showing striations and adductor muscle scars, scale bar $=200 \mu \mathrm{m}$. Figs 3-5 ARV, $0.96 \times 0.28$, ODP site 588, core 2, section 5, NMVP 197930; Fig. 3, detail of surface striations and rim of dorsal flange, scale bar $=25 \mu \mathrm{m}$; Fig.4, stereo pair ext. lat.; Fig.5, int. lat. Fig.6 ALV, $0.84 \times 0.25$, ODP site 588, core 2, section 5, NMVP 197929, int. lat. Figs 6-7 ALV, 51GC21, NMVP 197931: Fig. 7, stereo pair int. mid dors., scale bar $=50 \mu \mathrm{m}$; Fig. 8, stereo pair adductor muscle scars, scale bar $=20 \mu \mathrm{m}$; Fig.9, int. post. lat, scale bar $=50 \mu \mathrm{m}$. 


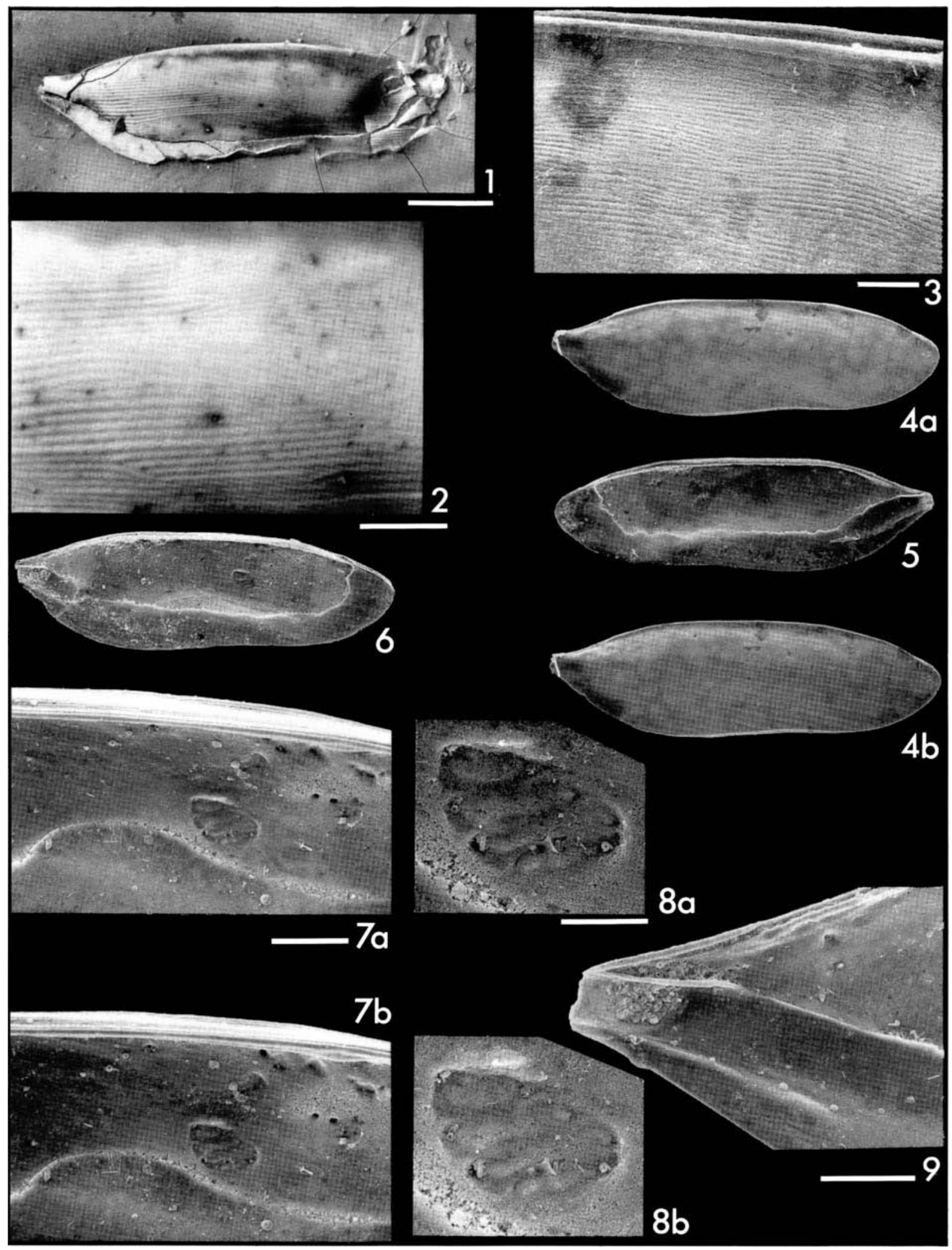


bathyal water depths in the western Pacific are usually widespread and long-ranging (Coles et al. 1990). By comparison, therefore, the restricted distribution of Glyphidocythere may reflect its relatively young (Pleistocene to Recent) existence. However, considering the extremely fragile nature of the valves of Glyphidocythere only exceptional preservation will reveal the genus in fossil samples. It is prudent, therefore, to be cautious when assessing the stratigraphical distribution of Glyphidocythere at this stage in our knowledge of the genus.

Its apparent restriction to low southern latitudes suggests that its distribution is strongly influenced by temperature and water mass structure. In the Coral and Tasman Sea, Glyphidocythere seems to be closely associated with the Antarctic Intermediate Water (AAIW). Examination of 45 modern Coral Sea sediment samples (ranging from $370 \mathrm{~m}$ to $3776 \mathrm{~m}$ ) revealed that Glyphidocythere has a narrow bathymetric range $(955 \mathrm{~m}$ to $1754 \mathrm{~m})$ that corresponds closely with the depth range of the AAIW in the Coral Sea $(800 \mathrm{~m}$ to $1750 \mathrm{~m})$. An oxygen minimum occurs at the base of the AAIW, associated with a phosphate maximum, and this could act as a barrier for downward migration of some ostracods, including Glyphidocythere.

Paradoxostomatids have only recently been reported from the deep-sea environment (Van Harten, 1990; Steineck et al., 1990). This may well be a reflection of their fragile nature as well as a failure of some workers to examine the fine fraction of samples. Glyphidocythere is the first formally described paradoxostomatid genus of the deep-sea. An additional as yet undescribed genus of the same family, possibly allied to Paracytherois, is also known to occur in the deep-sea environment worldwide (own unpublished data; Van Harten, lit. comm., 1991). Clearly the importance of this group in the deep-sea has been overlooked in previous studies.
Natural History) for the photography of Chapman's (1910) specimen and W. Meyboom for providing data of his Banda Sea material. M. Ayress acknowledges support of a post doctoral fellowship award at the Australian National University. Finally, our SEM photography could not have been done without the assistance of members of the EMU unit at the Australian National University.

\section{Manuscript received August 1992 \\ Manuscript accepted December 1992}

\section{REFERENCES}

Behrens, P. 1991. Ostracoda (Crustacea) from Lizard Island, northern Great Barrier Reef, Australia. II. The family Paradoxostomatidae Brady \& Norman, 1889. Helgoländer Meeresuntersuchungen 45, 143-163.

Bonaduce, G., Masoli, M., Minichelli, G. \& N. Pugliese. 1980. Some new benthic marine ostracod species from the gulf of Aqaba (Red Sea). Bollettino della Soc. Paleontologica Ital. 19(1), 143-178,

Chapman, F. 1910. On the foraminifera and Ostracoda from soundings (chiefly Deep-water) collected round Funafuti by H.M.S. 'Penguin'. J.Linn. Soc. Zool.30, 388-444.

Coles, G., Ayress, M. \& R. Whatley. 1990. A comparison of North Atlantic and Pacific Cainozoic deep-see Ostracoda. In: Whatley, R.C. \& Maybury, C. (Eds) Ostracoda and Global Events, Chapman \& Hall, 287-305.

Steineck, P.L., Maddocks, R.F., Turner, R.D., Coles, G. \& R. Whatley. 1990. Xylophile Ostracoda in the deep-sea. In: Whatley, R.C. \& Maybury, C. (Eds) Ostracoda and Global Events, Chapman \& Hall, 307-319.

Van Harten, D. 1990. Modern abyssal ostracod faunas of the eastern Mid-Atlantic Ridge area in the North Atlantic and a comparison with the Mediterranean. In: Whatley, R.C. \& Maybury, C. (Eds). Ostracoda and Global Events, Chapman \& Hall, 321-328.

Van Morkhoven, F.P:C.M. 1963. Post -Palaeozoic Ostracoda: Their Morphology, Taxonomy, and Economic Use. Volume II General Descriptions. 478pp. Elsevier, Amsterdam.

\section{ACKNOWLEDGEMENTS}

The authors thank John Whittaker (British Museum of

Table 1. Recorded distribution of Glyphidocythere funafutiensis (Chapman)

Western Pacific Ocean Off Funafuti:

$\begin{array}{llll}\text { Recent } & 1924 \mathrm{~m} & \text { approx. } 9^{\circ} \mathrm{S} & \text { approx. } 179^{\circ} \mathrm{E} \\ \begin{array}{l}\text { Coral Sea: } \\ \text { Recent }\end{array} & 1260 \mathrm{~m} & 14^{\circ} 50.11^{\prime} \mathrm{S} & 148^{\circ} 8.35^{\prime} \mathrm{E} \\ \text { Holocene to Rec. } & 1212 \mathrm{~m} & 14^{\circ} 57.00 . \mathrm{S} & 147^{\circ} 055.00^{\prime} \mathrm{E} \\ \text { Late Pleist. } & 1630 \mathrm{~m} & 15^{\circ} 32.505^{\prime} \mathrm{S} & 146^{\circ} 56.47^{\prime} \mathrm{E} \\ \text { Late Pleist. } & 1754 \mathrm{~m} & 15^{\circ} 55.00^{\prime} \mathrm{S} & 146^{\circ} 51.00^{\prime} \mathrm{E} \\ \text { Late Pleist. } & 1428 \mathrm{~m} & 15^{\circ} 56.19^{\prime} \mathrm{S} & 152^{\circ} 11.27^{\prime} \mathrm{E} \\ \text { Late Pleist. } & 955 \mathrm{~m} & 16^{\circ} 25.38^{\prime} \mathrm{S} & 146^{\circ} 12.91^{\prime} \mathrm{E} \\ \text { Recent } & 1328 \mathrm{~m} & 17^{\circ} 22^{\prime} \mathrm{S} & 152^{\circ} 33^{\prime} \mathrm{E} \\ \text { Recent } & 1076 \mathrm{~m} & 18^{\circ} 04.55^{\prime} \mathrm{S} & 147^{\circ} 39.53^{\prime} \mathrm{E} \\ & & & \\ \text { Tasman Sea: } & & & \\ \text { Early Pleist. } & 1533 \mathrm{~m} & 26^{\circ} 6.7^{\prime} \mathrm{S} & 161^{\circ} 13.6^{\prime} \mathrm{E} \\ & & & \\ \text { Banda Sea: } & & & 131^{\circ} 28.30^{\prime} \mathrm{E} \\ \text { Recent } & 618 \mathrm{~m} & 4^{\circ} 14.80^{\prime} \mathrm{S} & 131^{\circ} 31.00^{\prime} \mathrm{E} \\ \text { Recent } & 627 \mathrm{~m} & 4^{\circ} 13.00 \mathrm{~S} & \end{array}$

Grab 690/49.

Core VM24-157, $3 \mathrm{~cm}$ and $26 \mathrm{~cm}$

BMR core $51 \mathrm{GC} 21,225 \mathrm{~cm}$.

Core VM24-158, $33 \mathrm{~cm}$.

ODP Site 209, C1, S1, $75-80 \mathrm{~cm}$

ODP Site 822 , throughout top $9 \mathrm{~m}$.

Coretop VM24-162.

Grab 791/56.

ODP Site 588, C2, 55 .

Snellius II, G5, Station 40B Snellius II, G5, Station 42B. 


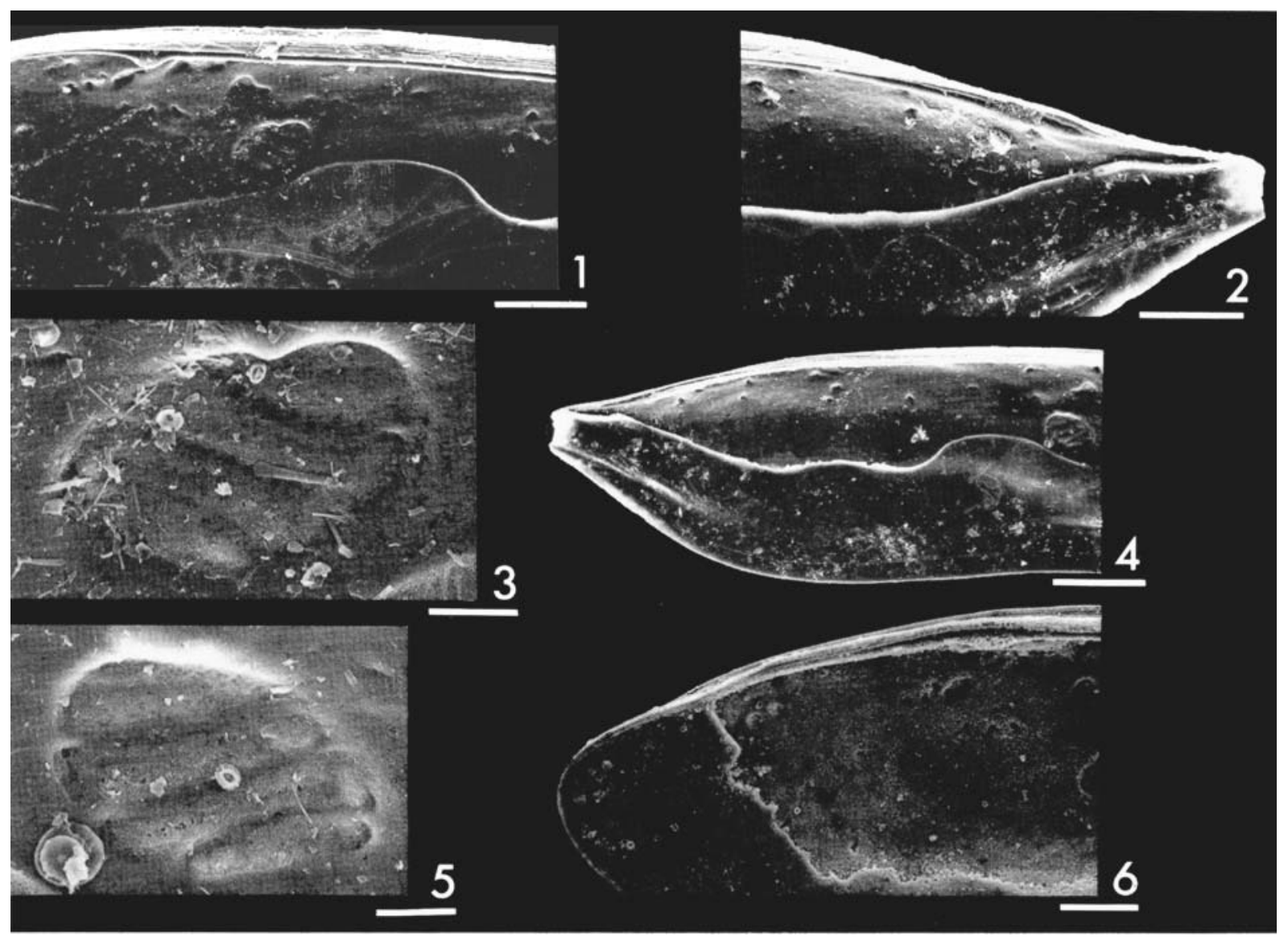

\section{Explanation of Plate 2}

All figures Glyphidocythere funafutiensis (Chapman). All dimensions are given as length $\mathrm{x}$ height in $\mathrm{mm}$.

Figs 1-3 ARV, $0.80 \times 0.22$, V24-157, NMVP 197932: Fig. 1, int. lat. med., scale bar $=50 \mu \mathrm{m}$; Fig 2, int. post. lat, scale bar $=50 \mu \mathrm{m}$; Fig. 3 , adductor muscle scars, scale bar $=10 \mu \mathrm{m}$.

Figs 4-5 ALV, $0.79 \times 0.22$, V24-157, NMVP 197933: Fig. 4, int. med.post. lat., scale bar $=80 \mu \mathrm{m}$.; Fig. 5, adductor muscle scars, scale bar $-10 \mu \mathrm{m}$.

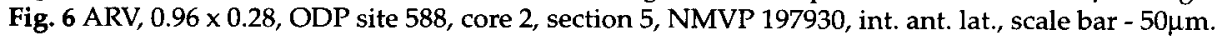

